\title{
Easy and fast obtaining of magnetic graphite ${ }^{1}$ FACIL E RÁPIDA OBTENÇÃO DE GRAFITE MAGNÉTICO
}

\author{
Franciane Batista Nunes², Theodoro da Rosa Salles², Enzo Cassol Vincensi², \\ Guilherme Oliveira Vargas², Leonardo Zancanaro Vidal'2, Amanda Carolina Pimentel ${ }^{3}$, \\ Franciele da Silva Bruckmann ${ }^{4}$ and Cristiano Rodrigo Bohn Rhoden ${ }^{5}$
}

\begin{abstract}
The exceptional properties of graphite, such as excellent thermal and electrical conductivity, corrosion resistance, allow this material to be widely explored in the industrial sector as an anatomic component in different material applications for instance lithium batteries. Magnetic nanoparticles, such as magnetite, presented biocompatibility, biodegradability, thermal conductivity, chemical stability, and the possibility of formation of nanocomposites. Thus, this work proposed the magnetization of graphite through a co-precipitation method that employs $\mathrm{FeCl}_{2}$ as an iron source. This methodology proved a magnetics nanocomposite with different amounts of magnetite incorporated and control of that. The results obtained through the instrumental analysis of XRD demonstrate a high crystallinity of the material and the presence of magnetite on the surface of the graphite. The average crystallite size, updated by the Scherrer equation, shows a decrease of the size as more nanoparticles are incorporated into the nanomaterial. Finally, it is possible to confirm the obtainment of a magnetic nanocomposite using a fast, economical and efficient method.
\end{abstract}

Keywords: nanotechnology, magnetization, magnetic nanoparticles.

\section{RESUMO}

As propriedades excepcionais do grafite, como sua ótima condutividade térmica e elétrica, além de resistência a corrosão permitem que este material seja amplamente explorado no setor industrial na forma de diferentes materiais tais como componente anatódico em baterias de lítio. As nanopartículas magnéticas, como a magnetita, apresentam biocompatibilidade, biodegradabilidade, condutividade térmica e estabilidade química além de elevada reatividade para formação de nanocompósitos. Dessa forma, este trabalho propôs a magnetização do grafite através de um método de coprecipitação que emprega $\mathrm{FeCl}_{2}$ como fonte de ferro. Os resultados obtidos através da análise instrumental de DRX permitiram evidenciar a cristalinidade do material além da incorporação da magnetita à superfície do grafite. O tamanho médio do cristalito, calculado pela equação de Scherrer, demonstrou uma diminuição de tamanho à medida que mais nanopartículas são incorporadas no nanomaterial. Dessa forma, pode-se confirmar a obtenção de um nanocompósito magnético empregando um método rápido, econômico e eficiente.

Palavras-chaves: nanotecnologia, magnetização, nanopartículas magnéticas.

1 Research study.

2 Graduation student at the Universidade Franciscana - UFN. E-mails: batistanunesfranciane@gmail.com; theodoro.rsalles @gmail.com; enzocassoleq@gmail.com; guilhermevargas2727@gmail.com; leo.j.vidalz@gmail.com

3 Civil Engineer. E-mail: amandacarolinapimentel@gmail.com

4 Pharmacist - Universidade Franciscana - UFN. E-mail: francielebruckmann2@gmail.com

5 Corresponding author - Laboratório de Materiais Magnéticos Nanoestruturados - LaMMaN - Universidade Franciscana UFN. E-mail: cristianorbr@gmail.com 


\section{INTRODUÇÃO}

Graphite (GR) is a material consisting of carbon atoms arranged in a hexagonal crystalline structure, its excellent thermal and electrical conductivity, in addition to corrosion resistance, allows its wide use in the industrial technology sector. (BAI et al., 2021; DEBELAK et al., 2007). Due to its high energy density, this compound is used as an anode in lithium batteries, as it gives them a long service life (ZHANG et al., 2020). Along with this, according to a study, the introduction of polymers such as poly (p-phenylene-2,6-benzobisoxazole) is capable of increasing the thermal resistance and mechanical properties of graphite. Which are superior to the 7075-aluminum alloy commonly used for heat dissipation in aerospace devices (ZHAO et al., 2021). Civil construction is another area where graphite can be used as an additive to improve the mechanical and microstructural properties of concrete. Peyvandi et al. (2018) reported a lower water absorption and an increase in the flexural and impact strength of concrete through the addition of graphite to cement pastes. Nevertheless, graphite is the starting material for the synthesis of graphene and graphene oxide, the latter being obtained through the oxidation and exfoliation of graphite (SALLES et al., 2020).

Magnetic nanoparticles, such as magnetite, exhibit biocompatibility, biodegradability, thermal conductivity, and chemical stability (FERREIRA-ERMITA et al., 2020; NKURIKIYIMFURA et al., 2020). The superparamagnetic property observed in magnetite is due to its small particle diameter less than $20 \mathrm{~nm}$ and the ability to align the atoms present in its structure through the approximation of an external magnetic field (TEJA and $\mathrm{KOH}, 2009$ ).

Its exceptional characteristics allow its application for in vitro bioseparation, adsorption of aquatic contaminants, tissue engineering, imaging, diagnosis, targeted drug delivery, and magnetic hyperthermia, among other applicabilities (Farzin, 2019; RHODEN et al., 2021). Luo and coauthors (2015) demonstrate the promising electrochemical properties, as well as those observed in graphite, of a coreshell compound of magnetite and carbon for anatomic application in lithium batteries. Similarly, a magnetic graphite nanocomposite exhibited an excellent ability to store electrochemical energy in a supercapacitor electrode, superior to the results obtained for the materials in their isolated forms. (SAYAHI et al., 2019).

Furthermore, Zhang and co-authors (2016) developed an electrode with high structural stability and equally high ion transfer kinetics for practical application in anodes commonly used in industry. Other studies report the anisotropic properties of graphite and magnetite nanocomposites, as well as their use as a carbon dioxide adsorbent under high pressure (ZUIN 2014; MISHRA et al., 2011).

Regarding the material applications and considering the lack of studies on graphite magnetization, this work proposes the magnetization of graphite through a co-precipitation method using iron II chloride, as unique iron source, to obtain a nanocomposite with different proportions of incorporated magnetite. 


\section{MATERIALS AND METHODS}

\section{OBTANTION OF MAGNETIC GRAPHITE}

In a $250 \mathrm{~mL}$ round-bottom flask containing $100 \mathrm{~mL}$ of ultrapure water previously deoxygenated $\left(\mathrm{N}_{2}\right.$ purge), $100 \mathrm{mg}$ of GR were added with different amounts of iron chloride II ( $\left.\mathrm{FeCl}_{2}\right)($ SigmaAldrich $^{\circledR}$ ), i.e., $500 \mathrm{mg}$ for $\mathrm{GR} \cdot \mathrm{Fe}_{3} \mathrm{O}_{4} 1: 5$, and $1000 \mathrm{mg}$ for $\mathrm{GR} \cdot \mathrm{Fe}_{3} \mathrm{O}_{4}$ 1:10. Sequentially ammonium hydroxide $\left(\right.$ Synth $\left.^{\circledR}\right)$ was added until the mixture reaches an oxidizing $\mathrm{pH}$ for precipitation of iron ions ( $\mathrm{pH} \approx 9.0$ ). Afterward, the mixture was submitted to ultrasonic irradiation (Elma, power 150 W) for $60 \mathrm{~min}$ at room temperature. Sequentially, the solution was poured with the assistance of a magnetic field and the solid was consecutively washed with methanol $\left(\operatorname{Synth}^{\circledR}\right)$ and acetone $\left(\operatorname{Synth}^{\circledR}\right)$. Subsequently, the material was dried in an oven (DeLeo) at $50{ }^{\circ} \mathrm{C}$ for total evaporation of solvents (RHODEN et al., 2021).

\section{CHARACTERIZATION OF NANOPARTICLES}

\section{X-RAY DIFFRACTION (XRD)}

X-ray diffraction analyzes were performed using a Bruker diffractometer, model D2 Phaser. The samples were macerated and arranged in the sample holder so that they were as smooth as possible (RHODEN et al., 2021).

\section{FOURIER TRANSFORM INFRARED SPECTROSCOPY (FTIR)}

The equipment used to characterize the samples synthesized in this work was Perkin-Elmer FTIR, model Spectro One. The tablets were obtained with $2 \mathrm{mg}$ of sample and $200 \mathrm{mg}$ of the support $(\mathrm{KBr})$. The spectrum appears, in the form of bands, resulting from the vibrations of the molecules when absorbing infrared radiation (RHODEN et al., 2021).

\section{AVARAGE CRYSTALLITE SIZE}

The average size of the crystallite (D) is related to the width of the half-height of the diffracted peaks, and the mesh parameter associated with the position of peaks is given by Scherrer Eq (1) (SALLES et al., 2020):

$$
D=\frac{K \lambda}{\beta \cos \theta}
$$


Where $\mathrm{D}$ is the average crystallite size, $\mathrm{K}=0.89$ is the constant that depends on the shape of the particles, $\lambda=1.5418 \AA$ the wavelength of the electromagnetic radiation, $\theta$ the diffraction angle and $\beta$ the width of the peak height (FWHM).

\section{RESULTS AND DISCUSSION}

The different reactions for the incorporation of magnetite on the GR surface are shown in the Table 1. The GR reaction with $\mathrm{FeCl}_{2}$ in a 1:5 ratio (R1), $353 \mathrm{mg}(95.13 \%)$ of the magnetic material was obtained; by using 1:10 ratio (R2), furnished $422 \mathrm{mg}$ of the magnetic nanocomposite corresponding 65.94\%. Thus, suggested a saturation of magnetite under the surface of the material (RHODEN et al., 2021).

Table 1 - Experimental conditions for the reaction to obtain magnetic nanocomposites.

\begin{tabular}{ccccccc}
\hline Reaction & Graphite & $\mathbf{F e C l}_{\mathbf{2}}$ & $\mathbf{F e}_{\mathbf{3}} \mathbf{O}_{\mathbf{4}}$ & Time (minutes) & Yield (mg) & Yield (\%) \\
\hline $\mathrm{R} 1$ & $100 \mathrm{mg}$ & $500 \mathrm{mg}$ & $270 \mathrm{mg}$ & 60 minutes & $352 \mathrm{mg}$ & $95.13 \%$ \\
$\mathrm{R} 2$ & $100 \mathrm{mg}$ & $1000 \mathrm{mg}$ & $540 \mathrm{mg}$ & 60 minutes & $422 \mathrm{mg}$ & $65.94 \%$ \\
\hline
\end{tabular}

\section{X-RAY DIFFRACTION (XRD)}

The X-ray diffractogram of graphite and graphite with different amounts of magnetite incorporated is shown in Figure 1. In the XRD of GR, it is possible to observe the presence of peaks around $2 \theta \approx 26.4^{\circ}(002)$ and $54^{\circ}(004)$, characteristic of pristine graphite (AIN et al., 2019).

Figure 1 - X-ray diffraction of nanomaterials.

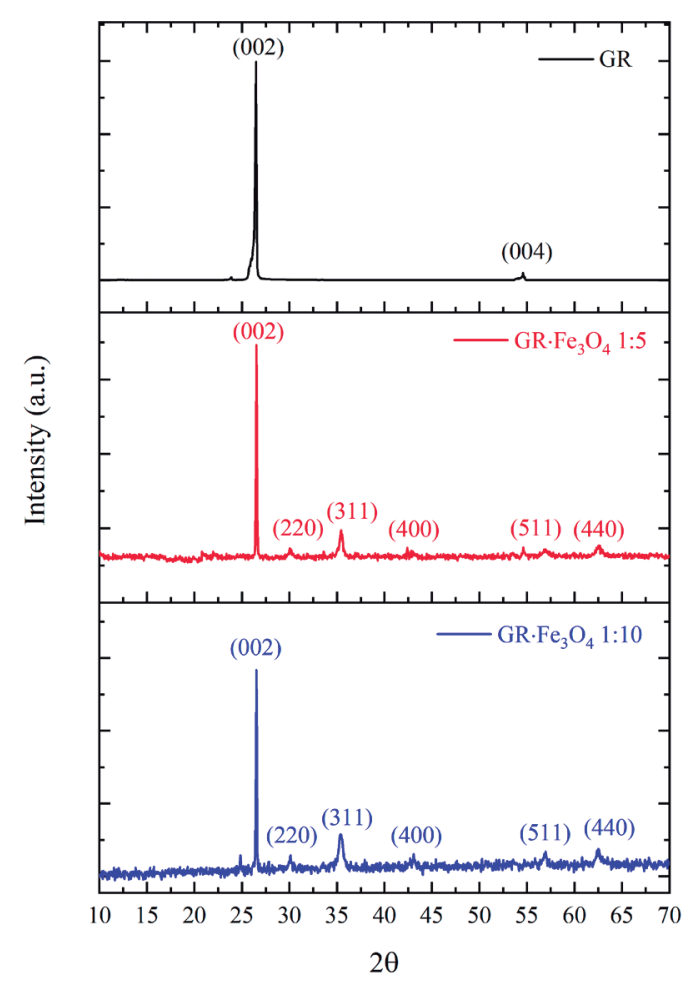

Source: Author's construction. 
For the magnetic nanomaterials, the appearance of peaks $2 \theta \approx 30.1^{\circ}, 35.3^{\circ}, 43.4^{\circ}, 57^{\circ}$ and $63^{\circ}$ corresponding to the indices (220), (311), (400), (511) and (440) in the graphs (BRUCKMANN et al., 2020). The position and relative intensity of the peaks is compatible with magnetite (JCPDS card no.19-0629).

\section{FOURIER TRANSFORM INFRARED SPECTROSCOPY (FTIR)}

The FTIR spectrum (Figure 2) shows for nanomaterials a band in $3400 \mathrm{~cm}^{-1}$ corresponding of $\mathrm{OH}$ groups indicating water absorption. Around $1500 \mathrm{~cm}^{-1}$ and $1000 \mathrm{~cm}^{-1}$ it is possible to interfere with bands characteristics of C-H and C-O groups (CHENG et al., 2019). For the magnetic nanocomposites, GR·Fe $\mathrm{O}_{4}$ 1:5 and $\mathrm{GR} \cdot \mathrm{Fe}_{3} \mathrm{O}_{4}$ 1:10, a peak at $618 \mathrm{~cm}^{-1}$ confirms the presence of $\mathrm{Fe}-\mathrm{O}$ bonds (RHODEN et al., 2021).

Figure 2 - FTIR of nanomaterials.

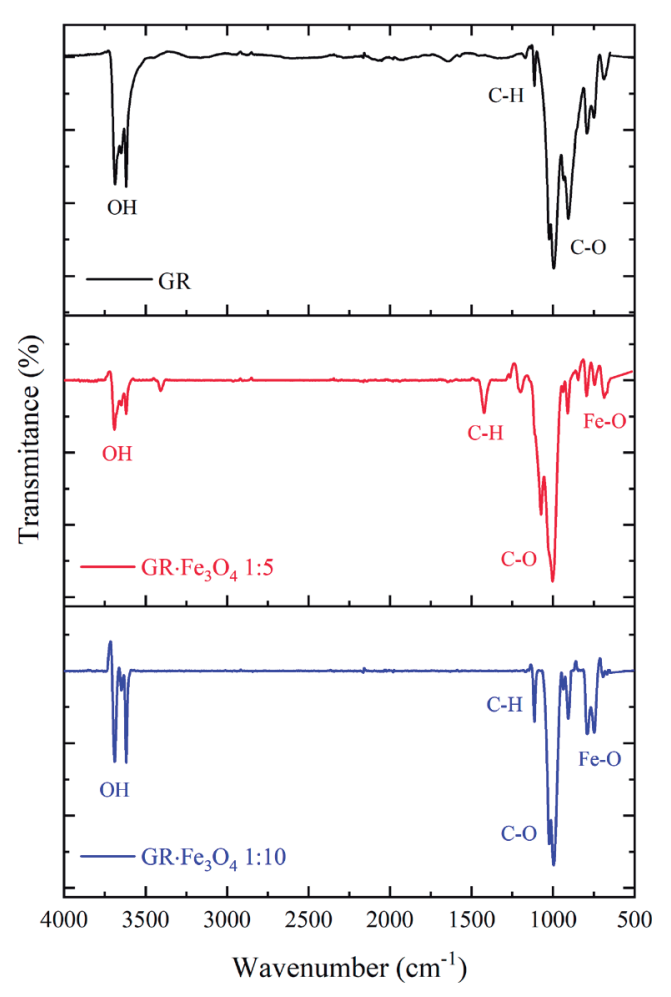

Source: Author's construction.

\section{AVARAGE CRYSTALLITE SIZE}

According to the average crystallite size determination by the Scherer equation (Table 2), the particle size of GR decreases with the magnetization process. US irradiations promote a physical phenomenon called cavitation, which is responsible for size reduction (ŁOŚ et al., 2013). Along with this, highly oxidizing media containing transition metals, such as $\mathrm{Fe}^{2+}$ in the 
presence of a base, increase the rate of hydrolysis of materials, therefore decreasing particle size (BRUCKMANN et al., 2021).

Table 2 - Average crystallite size of nanomaterials.

\begin{tabular}{cc}
\hline Sample & Size $(\mathbf{n m})$ \\
\hline $\mathrm{GR}$ & 81.10 \\
$\mathrm{GR} \cdot \mathrm{Fe}_{3} \mathrm{O}_{4} 1: 5$ & 58.21 \\
$\mathrm{GR} \cdot \mathrm{Fe}_{3} \mathrm{O}_{4} 1: 10$ & 43.21 \\
\hline
\end{tabular}

\section{CONCLUSION}

The magnetic nanocomposite was synthesized using $\mathrm{FeCl}_{2}$ under low energy requirements. The XRD and FTIR data demonstrate the incorporation of magnetite on surfaces of the graphite, and the Schererr equation shows a decrease of particle size for the magnetic nanomaterials due to the cavitation caused by ultrasonic irradiation. Thus, the results referred the easy obtaining, reduced process time, god yields and avoiding purification steps.

\section{REFERÊNCIAS}

AIN, Q. T. et al. The systemic effect of PEG-nGO-induced oxidative stress in vivo in a rodent model. Beilstein journal of nanotechnology, v. 10, n. 1, p. 901-911, 2019.

BAI, L. et al. Preparation and properties of copper-plated expanded graphite/copper composites. Tribology International, p. 107094, 2021.

BRUCKMANN, F. S. et al. Synthesis, characterization and cytotoxicity evaluation of magnetic nanosilica in L929 cell line. Disciplinarum Scientia| Naturais e Tecnológicas, v. 21, n. 3, p. 1-14, 2020.

BRUCKMANN, F. S. et al. Synthesis, Characterization, and Biological Activity Evaluation of Magnetite-Functionalized Eugenol. J. Inorg. Organomet. Polym. Mater. Accepted, 2021.

CHENG, M. et al. Synthesis of graphene oxide/polyacrylamide composite membranes for organic dyes/water separation in water purification. Journal of Materials Science, v. 54, n. 1, p. 252-264, 2019.

DEBELAK, B.; LAFDI, K. Use of exfoliated graphite filler to enhance polymer physical properties. Carbon, v. 45, n. 9, p. 1727-1734, 2007. 
FERREIRA-ERMITA, D A C et al. Characterization and in vivo biocompatibility analysis of synthetic hydroxyapatite compounds associated with magnetite nanoparticles for a drug delivery system in osteomyelitis treatment. Results in Materials, v. 5, p. 100063, 2020.

LEE, S. J. et al. Synthesis of highly magnetic graphite-encapsulated FeCo nanoparticles using a hydrothermal process. Nanotechnology, v. 22, n. 37, p. 375603, 2011.

ŁOŚ, S. et al. Cleavage and size reduction of graphite crystal using ultrasound radiation. Carbon, v. 55, p. 53-61, 2013.

LUO, Y. et al. Preparation of core-shell porous magnetite@ carbon nanospheres through chemical vapor deposition as anode materials for lithium-ion batteries. Electrochimica Acta, v. 154, p. 136-141, 2015.

MISHRA, A. K.; RAMAPRABHU, S. Magnetite decorated graphite nanoplatelets as cost effective CO 2 adsorbent. Journal of Materials Chemistry, v. 21, n. 20, p. 7467-7471, 2011.

NKURIKIYIMFURA, I. et al. Temperature-dependent magnetic properties of magnetite nanoparticles synthesized via coprecipitation method. Journal of Alloys and Compounds, v. 846, p. 156344, 2020.

PEYVANDI, A. et al. Evaluation of the reinforcement efficiency of low-cost graphite nanomaterials in high-performance concrete. Ksce J. Civ. Eng, v. 22, p. 1-8, 2018.

RHODEN, C. R. B. et al. Study from the influence of magnetite onto removal of hydrochlorothiazide from aqueous solutions applying magnetic graphene oxide. Journal of Water Process Engineering, v. 43, p. $102262,2021$.

SALLES, T. et al. Graphene oxide optimization synthesis for application on laboratory of Universidade Franciscana. Disciplinarum Scientia| Naturais e Tecnológicas, v. 21, n. 3, p. 15-26, 2020.

SAYAHI, H. et al. Facile and economical fabrication of magnetite/graphite nanocomposites for supercapacitor electrodes with significantly extended potential window. Journal of Alloys and Compounds, v. 778, p. 633-642, 2019.

ZHANG, H. et al. A spherical Sn-Fe 3 O 4@graphite composite as a long-life and high-rate-capability anode for lithium ion batteries. Journal of Materials Chemistry A, v. 4, n. 26, p. 10321-10328, 2016. 
ZHANG, H. et al. Graphite as anode materials: Fundamental mechanism, recent progress and advances.

Energy Storage Materials, 2020.

ZHAO, X. et al. Bioinspired modified graphite film with superb mechanical and thermoconductive properties. Carbon, v. 181, p. 40-47, 2021.

ZUIN, A. et al. Anisotropic magnetic carbon materials based on graphite and magnetite nanoparticles. Carbon, v. 77, p. 600-606, 2014. 